\title{
Legitimacy, violence and extraction in the practice of building states
}

[T]o govern men as to produce and collect goods is inseparable from the specific modes of the distribution and modulation of violence. (Mbembe 1991a: 7)

\section{Ruling over people}

W hatever other challenges peacebuilding faces, whether administrative reform, economic reactivation or the stabilisation of conflicts, it poses peacebuilders with the basic question of how to assert state rule. Peacebuilding has a state-making ethos and, as Weber argues, states are 'associations of rule' (1978: 51). Since 1945, a significant quantitative and qualitative development in the doctrines of intervention and conflict management has made state-society relations the sphere of international intervention. ${ }^{1}$ These operations have included programmes for economic, security sector and civil administration reform, as well as for promoting certain civil society activities. Since 2001, when so-called failed states were designated as the major cause of conflicts, interventions have aimed at the transformation of the state apparatus, supporting governments and the central administration, in so far as the state is considered the cornerstone for the end of conflict and for the establishment of a long-lasting peace. Operations such as those in Bosnia, East Timor, Afghanistan and Kosovo heralded an era in which peacebuilding is statebuilding, by whatever other name it is called (Chesterman 2004). Current policy indicates that statebuilding has survived other aspects of the liberal peace agenda (Bliesemann de Guevara 2010; Hameiri 2014), and, in fact, it has a wide consensus from Western and non-Western governments (Curtis 2013).

These processes have generally been studied under a global governance framework. The very few historical-sociological approaches demonstrate that little is known about how the reconstruction of state authority impacts on peacebuilding (Bliesemann de Guevara 2012, 2015; Jung 2008; Migdal and Schlichte 2005). As Newman argues, 
In historical perspective statebuilding has generally been a coercive and often a violent process. Statebuilding involves imposing a unified, centralised state and subjugating peripheral regions, securing border areas and imposing regulation, institutions, taxation and control. This has been a violent process because it threatens the interests of recalcitrant actors and it encounters outlying resistance which must be suppressed. [...] In stark contrast, in the twenty-first century scholars and policy analysts interested in peacebuilding portray peacebuilding and statebuilding as complementary or even mutually dependent. (2013: 141)

However, Newman himself falls short of fully developing a historical-sociological approach. This chapter analyses statebuilding from the practices and patterns that constitute it presently and historically. It argues that peacebuilding as statebuilding is based on the same practices of coercion, extraction and claims to legitimacy that define state-making, and that these practices are the ground for resistance. Resistance reflects not just issues of bad governance, or a rejection of internationally led agendas that impinge on a local culture. It reflects the experience of war, poverty, and political processes as intolerable and humiliating. However, as Eric Wolf states, social science cannot be restricted to the study of 'self-contained' societies (1982: 385). Resistance needs to be seen as an expression of an experience that is historical and inseparable from global political and economic processes.

Peacebuilding shares with state-making the claims to legitimate authority to distribute rights, privileges, violence and economic resources. It is based on a high-modernist discourse of peace, democracy and development that promises to be the solution to the problems (post-)conflict states and societies face; it is based on the support of a strong winning party or a power-sharing agreement, in a way that militarises government; and it continues or establishes new ways of extraction that tend to reinforce patterns of accumulation and dispossession.

These three elements (coercion, capital and legitimacy), which relate to the legacy of Max Weber, are part and parcel of a widely embraced tradition about what states are and how they came into being. As Hintze pointed out, Weber's insight is to have revealed the state as an 'institutional enterprise possessing coercive force', tearing down ideological conceptions of the state as a neutral and collective good (cited in Anter 2014: 40). But this approach has its limitations.

Hannah Arendt criticised Weber for having merged violence and power. She argued that violence does not create power, but destroys it (1970: 35-8). For Arendt, the issue is not to have linked violence with the exercise of state violence but to have established a causal and ontological link. Weber is also at the root of the 'bellicist' account, which, although it establishes what Teschke calls the "core hypothesis constitut[ing] the dominant paradigm of state formation theory in contemporary scholarship', does not fit the formation of all states (2003: 
119). ${ }^{2}$ The 'bellicist' account entails a process which Norbert Elias (1982) saw as having 'two phases'. In the first phase, the threat and preparation for war provides the momentum to recruit men and taxes, simultaneously creating the incentives to centralise and develop institutions for the securing of the territory. A second phase takes place when this institution is democratised. The problem of this account is that it is focused on the process of power concentration and later democratisation that ultimately reflects the unfolding of the modern European nation-state.

The benefit of the Weberian tradition is to offer a relatively simple formula that allows us to sharpen the perspective about the continuities, changes, specificities and generalities of different states and different past and contemporary state-making processes. In this book, state-making (and peacebuilding/ statebuilding) is a process of asserting, consolidating and exercising rule through the management of violence and wealth that has both national and international elements. This simple formula fits a wide range of states, and in particular African states, which have been forged out of processes marked by violence and extraction, with claims to legitimacy. For Achille Mbembe, rule and states in Africa were consolidated during colonisation through two different forms of violence, one of conquest under a claim of 'right to rule' and another of 'domestication' under the discourse of civilising the natives (2001: Ch. 1). The particularities of peacebuilding come from the contexts and international structure in which they are embedded. The contemporary reconstruction of state authority after conflict has not represented an authority resting on popular consent, but the political compromises of different parties through power sharing which international actors have advocated for. The discourse of peacebuilding informs these strategies and underpins the need for these compromises, also affording a platform for legitimising international actors. Recognising common practices as longer patterns of state-making that link different kinds of states with different historical developments allows us to depathologise 'failed' states.

The chapter starts with a discussion of Weberian historical sociology in order to analyse not only coercion, extraction and claims to legitimacy as constitutive practices of states, but also how informal and plural forms of governance do not make the DRC pathological; in fact, they characterise the nature of peacebuilding as a plural and improvised form of ruling. This is illustrated with some empirical examples in the fourth section of the chapter. Before that, a third section analyses both Africa's normality and exceptionalism. It first discusses the main critiques that Weberian historical sociology has received in making African states a 'shadow' of the ideal European states (cf. Ferguson 2006) and then goes on to analyse particularities of African states through the work of Achille Mbembe. The section highlights the need to take Africa's historicity into account in order to understand its politics and its interconnected nature with global 
politics. The chapter facilitates an analysis of the object of resistance beyond international actors, while also pointing to several challenges of theorising resistance in this context. These will be more fully developed in the following chapters.

\section{Practices and patterns of state-making}

Historical sociology has provided some of the most extensive research and theorisation on state theory and state formation. It is not unitary, as there have been different approaches within it, nor does it necessarily provide the best account. It suffers from important critiques, since it is underpinned by Weber and his Eurocentric approach. Other theories have also added important insights. Michel Foucault, post-structuralism and feminism have identified the constitutive links between the private and public arenas, the plural and decentralising exercise that power relations within states give rise to and the important relationship between formal and informal processes (Ashley 1988; Foucault 2008, 1991; Wilmer 2009). Some of these features, explored below, are synthesised in Achille Mbembe's theory of the African political space.

Historical sociology, and some elements of Weberian theory, are still useful to observe not the specificities of the European state but the broader patterns through which states assert rule. Historical sociology is a corrective to three misunderstandings commonly made in peacebuilding literature and policy, which are that: (1) statebuilding, as an internationally led enterprise, is external to the actual practice of ruling and is a solution to the problems of war; (2) the state is a naturally, and not historically, occurring institution, and its problems can be solved by changing its internal dynamics, without addressing the inequalities and dynamics of the global political economy; and (3) the state is the 'hero', able to harmonise competing interests inside and outside (cf. Ashley 1988). This form is an ideal version of the state as a service provider, with a central and coherent administration based on routinised bureaucratic practices and with high levels of legitimacy to distribute and manage wealth and violence, based on the rule of law. Peacebuilding thus exposes an ideal version of the Weberian state, which not only sanitises its history and disregards the constraints that the international context imposes, but ascribes to it features that do not belong to even the most organised and consolidated states.

By contrast, (post-)conflict states and, in particular, African states are characterised by neopatrimonial practices. As discussed below and in Chapter 3, the sources of state failure and of conflict come down to how violence, wealth, rights and services are distributed through personal networks of patronage rather than rational, bureaucratised procedures. Yet this understanding ceases to be a policy or analytical argument and becomes normative political theory about how society should be organised and about the way political and economic goods should be distributed. 
An analysis of historical sociology shows that centralisation, monopoly of violence, impersonal bureaucratised practices and legitimacy are all limited and contested. The hallmark of Weberian theory is to see the state through the lens of the institutionalisation and legitimation of the means of coercion which grants the state the organisational capacity to administer the population of a particular territory (Weber 1978: 54-6). Territory and rule, backed by force under a claim to legitimacy, were all necessary elements in the definition of a state. Weber is generally misunderstood on this, for he never implied that the state would have the monopoly of coercion, just that it would have the legitimate means of coercion. This could be extended to his vision of ruling. Weber looked at the state, and indeed at every social relationship, as an association in which two elements, force and rule, were combined (Anter 2014: 46). In fact, 'the state as a relation of rulership consisting of command and compliance [became] the paradigm of political thought in the later nineteenth and early twentieth centuries' (Anter 2014: 48).

Contemporary historical sociology has added nuances to a Weberian state theory that many consider unfinished (Anter 2014: 1-2; Mann 1993: 58). Mann's 'institutional statism' sought to synthesise two currents that until then had seen the state either as a place to host particular interests or as an actor, entirely driven by an elite administration. Mann's categorisation allows us to see some of the flaws in the approaches to the conflict in the DRC and current peacebuilding policy. The first current, which sees states as places, has a class-based/Marxist version and a liberal/pluralist version. Class-based theorists think that states are the result of class struggle at two crucial points during feudalism and early capitalism. This gives states their capitalist character and their fundamental function as instruments for 'capital accumulation and class regulation' (Mann 1993: 45). In many respects, though generally outside the historical-materialist framework, this links to the vision of resource wars and post-colonial states as instruments for the enrichment of the elites and their allies that end up serving the status quo within states (Deneault 2008; Renton, Seddon, and Zeilig 2007). Mann's liberal version of this approach, pluralism, is for him 'liberal democracy's (especially American democracy's) view of itself' (1993: 45). It accounts for the birth of the democratic state through the rise of pressure groups contesting old regimes and their institutions and increasing popular participation (Mann 1993: 45 ). This reflects the vision of much peacebuilding policy and liberal scholarship. An old, undemocratic 'neopatrimonial' state is the cause of conflict, it is illegitimate and it needs to be replaced by a legitimate democratic state where a wide spectrum of the population is represented and is able to participate (ISSSS 2013; Lemay-Hébert 2009; Fukuyama 2004). In both versions of the 'state as a place', society is almost equated with the state and, as Mann notes, there is no account of how the state operates (at least partly) 
autonomously, nor of how it is intervened and constituted by transnational pressures (1993: 47).

Mann's second current refers to those who think of the state as an actor, or what he sees as 'true elitists' (1993: 48). This is a branch of state theory initiated by Mosca and Pareto, and later elaborated on by Oppenheimer and Skocpol. The latter version posits that states have autonomous power to distribute resources and act in their own geopolitical environment. Whereas this approach managed to clearly identify states as actors in a world of states, it still took the state as unitary and systemic, too concentrated on the actual rulers, and forgot to account for transnational actors and international interference, as well as state-society relations (Mann 1993: 48-52). The practice and priorities of many peacebuilding operations also reflect a focus on the actual government. As mentioned before, this has been the case of many flawed democratic elections, power-sharing agreements and, in general, the focus on the security apparatus of the state.

Mann's proposal is to see state power emanating from the autonomous power of different political institutions, as it has been able to constrain past and present struggles. The resulting institutionalised power represents 'state power' and not just 'elite power', which simultaneously emphasises not just that 'elites' dominate civil society but that 'all actors are constrained by existing political institutions' (Mann 1993: 52). The virtue of this approach, to which Skocpol, Tilly, Weir and others contributed, is to present the state's nature as 'chaotic, irrational, with multiple departmental autonomies, pressured erratically and intermittently by capitalists but also by other interest groups' (Mann 1993: 53). By this means Mann captures the nature of states as configured by a complex interconnection of historical processes and actors. Tilly's particular contribution is to capture the practices of state-making as common to the exercise of state authority.

Tilly's landmark study on state formation opens with the story of Hammurabi's conquest of the nearby Mesopotamian city-states around late $18 \mathrm{BC}$, asserting that it was representative of patterns of state formation in history (1990: 1). Tilly acknowledged that the deployment of a discourse that legitimised Hammurabi's rule as divine and just was important to the process of subjecting the population of these states to his own Babylonian rule. Hammurabi claimed a right and an obligation to make laws, under the divine dictate of the god Marduk, thus further vilifying all resistance as going against divine will (Tilly 1990: 1). For Tilly, although this conquest contained an important cultural, religious and rule-making exercise, it was coercive power that allowed Hammurabi to create his state. The underlying theory is that state-making is an act of power concentration determined in large part by mutually influencing external and internal pressures. Different combinations of these dynamics provided different types of states, but the pathways were similar. ${ }^{3}$ The rivalry and 
conquest of elites provoked wars; this provoked the need for military conscription and taxation, centralising state power and turning it into an instrument of coercion against the population and for the subjugation of rivals. The absolutism of this new institution was transformed into more democratic forms of government only several centuries later, through wars and revolutions, and not through a social contract (Tilly 1990: 110-19). State-society bargaining, added to the development of commercial, military and diplomatic alliances, gave way to the modern European state system (Tilly 1990: 15-22). This should not be read in terms of the necessary pathway all states should or would follow in an evolution towards better and more progressive ways of ruling. What Tilly is arguing is that democracy was not part of the natural evolution of European states; it was a hard and long struggle, fought over centuries. In fact, for Tilly:

At least for the European experience of the past few centuries, a portrait of war makers and state makers as coercive and self-seeking entrepreneurs bears a far greater resemblance to the facts than do its chief alternatives: the idea of a social contract, the idea of an open market in which operators of armies and states offer services to willing consumers, the idea of a society whose shared norms and expectations call forth a certain kind of government. (1985: 169)

For Tilly, war-making and the taming of competitors for state-making was not about annihilating them so much as it was a process of fostering alliances. This is well exemplified by Tilly's thesis of state-making as organised crime (1985), which also sheds light on the limited legitimacy and limited monopoly of means of violence that states have. By this measure, states were protection rackets. State-makers rise as protectors of allies and competitors when the threats are real, but also when they are invented. In order to foster rule, channel accumulation and gain allies, the government could invent a threat and portray itself into a protector in the eyes of elites, transferring wealth and punishing the population if necessary (Tilly 1985: 171). Organised crime was not a challenge to the state but its actual source, used to gather elite support, maintain extraction and yield coercive power. In this equation, the distinction between " "legitimate" and "illegitimate" force makes no difference to the fact' (Tilly 1985: 171). For Tilly, the fact is that state authority requires the management and, if possible, the monopoly of violence (1985: 171). The Tillean account of coercion and accumulation offers the possibility of understanding coercion and extraction as connected to state-making not only as an account of the formation of a new state, but as continuous practices of the assertion of state authority.

These authors focus on a process that has as its outcome the European state, but their vision is only partial. Additionally, they take the European state as a self-made miracle, not accounting for the input that colonisation had. Mann's definition of the state centres on the rise of differentiated institutions and personnel whose power radiates from the centre, that are linked to a particular 
territory and exercise authority with the capacity to impose binding rules backed by 'some organized physical force' (1993: 55). Although Mann acknowledges the limited monopoly of force, and the 'capacity' rather than the 'legitimacy' to impose rules, he still emphasises centralisation and bureaucratisation as defining state features. This does not, however, account for shared and delegated authority. Mann also saw states as based on and constituted by a class system as well as patriarchy, but separated the specific mode of production from the mode of rule-making and force. In particular, Mann (1984) saw militarism as separate from the rise of capitalism and contingent to it, originating in the geopolitical needs of states. This accounts only partially for the rise of contemporary African states, so tied to the capitalist and militaristic enterprise of European expansion. In general, the Weberian account of the state centres excessively on the outcome of the European state, rather than on an open-ended process with common practices, where processes of legitimation and contest are permanent. Mann and Tilly, however, internationalise Weber's account, adding the impact of international processes, actors and structures on the local environment. They also show that coercion and extraction are not always seen as legitimate and that resistance shapes states.

Bourdieu offers a practice-based understanding of states and state formation, while remaining within a Weberian framework. He sees states as the result of the accumulation of different forms of capital that are rooted in the preparation for war, but offers insight into the ways these practices have been routinised. For Bourdieu (1994), the requirements of war involve the formation of 'capital of physical force', which simultaneously implies the formation of 'economic capital'. This is expanded with 'information capital', which includes statistics and census, cartography and cultural means. The different forms of capital require 'symbolic capital', that is, legitimacy. These different forms of capital do not only account for the rise of the state as kings, armies and their agents, but also for the bureaucratisation of state rule. This means the systematisation, routinisation and depersonalisation of functions related to the management and concentration of those forms of capital. The transition from the administration of justice directly by the king with his immediate vassals to the administration of justice by a specialised body under a codified law is very important for legitimacy. Yet legitimacy is always limited because consent is limited (Bourdieu 1994: 14-15).

Different forms of resistance have impinged upon state-making. The heterogeneity of the population was a difficulty for establishing state rule across Europe, and this became the target of increasing homogenisation in terms of language, religion, and administration (Tilly 1990: 107). The more these types of mechanisms disturbed the subordinate population, the more resistance they gathered (Tilly 1990: 100). Subordinate groups were likely to "[employ] the "weapons of the weak"' (James Scott, cited in Tilly 1990: 101), 
but these turned into outright revolt when the state's actions were particularly damaging to their collective identities, when they had strong ties between them or with national or international elites and when they had identified the state's vulnerabilities. States have impacted on the form resistance has taken, but that resistance has also determined the form of the state (Tilly 1990: 117-22).

Two initial conclusions come from the above. Firstly, states have been forged through long historical processes and continue to be shaped by multiple pressures. Secondly, despite the complexity that states have achieved, they retain a common pattern in their rule-making efforts through the management of violence and wealth under a claim to legitimacy. Peacebuilding is then a process of supporting state claims, while establishing claims of its own. State-making, even in its contemporary form, entails practices of coercion and extraction, both symbolic and material, that simultaneously demand the recognition of legitimate authority. Extraction needs not to be seen only in terms of tax extraction. As Tilly argues, 'capital' is what allows the state to finance its war-making, statemaking and the continuation of the running of the state, and this comes from taxes as well as from credit, debt and rents (1990: 84-6). These coercive and extractive practices, whether in the form of the threat or the use of force, taxation, wealth and rights redistribution, are the object of resistance. Yet much more needs to be said about how specifically these aspects and dynamics are represented in a context of war and peacebuilding in contemporary Africa. Additionally, a response to the Eurocentrism of this Weberian legacy of historical sociology is required.

\section{African states: challenges, particularities and generalities}

It has been precisely a Weberian account of the state that has underpinned the vision that the DRC does not exist or that it does not function in the right way (Eriksen 2011: 237-9). For Migdal and Schlichte (2005: 4) a Weberian 'image' of the state as 'coherent, fairly unified actors, set apart from, or above, other social organizations' has permeated both academic research and policy-making. In fact, for Migdal, the state is a 'field of power marked by the use and threat of violence and shaped by 1 ) the image of a coherent, controlling organization in a territory, which is a representation of the people bounded by that territory, and 2 ) the actual practices involving those staffing its multiple parts and those they engage in their roles as state officials' (2004: 15-16). The use of informal extraofficial channels does not mean that these are not geared towards ruling and asserting authority. Migdal and Schlichte agree with the view that violence is central to state power (2005: 16). Their view is that this power, which affects practices of norm-making, tax and labour extraction, bureaucratic administration and the use of force, will vary across states (Migdal and Schlichte 2005: 
16). A focus on actual practices beyond legal/illegal, formal/informal or public/ private divides is what can demonstrate the ways in which states operate (Migdal and Schlichte 2005: 16 and 31). This focus has also taken scholars to note the multiple forms of governance that have emerged as a result of civil society groups taking over, as well as from the consequences of war (Meagher et al. 2014; Titeca and De Herdt 2011); although, as De Herdt and Sardan argue, the implication of civil society in governance and informal arrangements is hardly a new phenomenon (2015: 3). For Achille Mbembe, as will be seen below, what defines African states is their entanglement with time, processes and dynamics that make them assert their authority by means of coercion and extraction under claims of legitimacy through private and informal channels. The ideal version of Weberian state theory underpinning the measurement of the capacity and propriety of states raises important ethical implications and leaves many aspects of African states unexplained.

\section{Ethical challenges to the bellicist account}

One of the main challenges to the bellicist account is its Eurocentric narrative, which has an ethical and a methodological dimension. The experience of African state formation has particular specificities marked by the experience of slavery and colonisation. As Makau Mutua notes (2001), this experience configures different a state-subjects relation to that of Western states, which is based on struggles embedded in the processes of industrialisation and the rise of the bourgeoisie.

The bellicist account's 'elision of empire' has been the target of critiques (Carvalho, Leira and Hobson 2011: 737). Bhambra (2007) argues that the Weberian-inspired narrative has a civilisational bias. Its narrow view of processes outside violence and war has artificially created a 'success' story by which to measure others. Yet it is important to recognise that even in the relatively parochial narrative of European state formation its sources of authority, as Tilly points out, are not consent and democracy, but war, coercion and accumulation. When colonisation is added to this narrative, which, as Bhambra (2010) argues, is constitutive and not a consequence of modernity, it shows that European states were not entirely self-made but have benefited from extraction, exploitation and war in the colonies.

The challenge to the Eurocentric versions of the rise of Europe and capitalism does not necessarily undermine the argument that war, coercion and accumulation played a role in the emergence of states. Hobson's research (2004) shows how tools and ideas fundamental for the rise of 'the West' were the result of the copying, appropriation and exchange of inventions and technologies developed in East Asia and North Africa. With the example of Central America, Holden (2004) sees that the climax of state power, well into the twentieth 
century, was not so much the concentration of coercive power in the hands of the state but its dispersal amongst the population. Common to these accounts is what Veena Das saw as the fundamental flaw in Weber's argument: "The state's monopoly over what Weber called "legitimate" violence does not end violence - it redistributes it' (2007: 4). The flaw is in having concentrated exclusively on the mechanisms of centralisation rather than on coercive and military practices as important to the process.

Other critiques argue that war, in particular, has not played such a fundamental role in Europe, and less so elsewhere. Teschke notes that royal marriages and the process of class formation in Europe gave way (somewhere close to the early nineteenth century, and not the Westphalian peace) to the so-called modern state system (2003: 11; 220-5). He also challenges the notion of the concentration of coercive mechanisms. He argues that:

due to peasant possession of the means of subsistence, feudal mobility enforced access to peasant produce by political and military means. Since every lord reproduced himself not only politically but also individually on the basis of his lordship, control over the means of violence was not monopolised by the state, but oligopolistically dispersed among a landed nobility. (2003: 46)

This resonates with the state-formation theses outside Europe (Clapham 2000; Herbst 2000; Young 1997). Patterns of state formation in central Africa have been varied. The Great Lakes region, together with the Ethiopian highlands, have had 'the longest traditions of relatively centralized state structures' (Herbst 2000: 11). These have been the result of migration flows and the influence of the centralising exercises of political rule in the Kongo, Luba-Lunda and the Kunda kingdoms (Muiu and Martin 2009: 104). Wa Muiu and Martin argue that the Kongo kingdom had developed a highly centralised structure around a single currency, a centralised army and the king (Muiu and Martin 2009: 104-5). However, this power was articulated on a mutual assurance of authority between the king and local elites. Protection and tribute formed a network of political authority where elites shared power, and their allegiance to the king was linked to religious, identity, security and economic agendas (Ndaywel è Nziem 2009: 135-6). State-making was not just about concentrating power away from competitors but also about sharing sovereignties. Resistance on the part of the population took the form of flight from authorities. Distance to the centralised administration of power meant laxer power, and this encouraged authorities and elites to extend their rule through alliances rather than war (Muiu and Martin 2009: 104).

Looking at actual practices of governance, James Scott provides a different account, arguing that what drives state-makers is 'high modernism', that is, the 'faith' in administration, science and technocracy to organise people and nature in a productive way (1998: 4-6). As Proudhon argues, 
To be ruled is to be kept an eye on, inspected, spied on, regulated, indoctrinated, sermonized, listed and checked off, estimated, appraised, censured, ordered about.... To be ruled is at every operation, transaction, movement, to be noted, registered, counted, priced, admonished, prevented, reformed, redressed, corrected. (Cited in Scott 1998: 183)

Statebuilding in this version is an exercise of control that aims at making the population and the environment legible, hence simplified and homogenous. These practices are still underlined by the logic of asserting rule and extracting consent, taxes and labour under the threat of or use of coercion. Additionally, in the DRC these homogenising practices have not been the hallmark of the statebuilding exercise. The largest census undertaken was done only in 2011 for voting purposes. ${ }^{4}$ Even the biometric census completed in 2015 for the military and its new phone-payment system do not change the fact that governance practices do not rely on turning the Congolese into consuming and working taxpayers (EEAS 2015; UNDP 2010).

There is a deeper question of the feasibility and ethics of offering an intelligible reading of the forms of social and political imagination in contemporary Africa solely through conceptual structures and fictional representations used precisely to deny African societies any historical depth and to define them as radically other, as all that the West is not (Mbembe 2001: 11). Not least, the European state, most prominently embedded in an idealised service-provider form in policy documents, makes the African state a bad state. Dunn noted that '[s]ince citizenship, territorial integrity, and monopoly on the tools of coercion are all considered prerequisites for statehood, this raises serious doubts about whether African states are in fact states at all' (2001: 55). Dunn shows how common misunderstandings in both IR and Africanist state theory, which take the state as a given, impose a European model as shorthand for what states are. As a result 'African' states are applied all sorts of 'madlibs' - adjectives to be inserted in a blank space next to the word 'state' - all of them accentuating its lack of something, its failure. Dunn's (2001: 46) survey of these 'labels' includes:

'failed' (Leys 1976), 'lame’ (Sandbrook 1985), 'fictive’ (Callaghy 1987), 'weak' (Rothchild 1987), 'collapsing' (Diamond 1987), 'quasi' (Migdal 1988), 'invented' and 'imposed' (Jackson 1990), 'shadow' (O’Brien 1991), 'over-developed' and 'centralized' (Davidson 1992), 'swollen' (Zartman 1995), 'soft' (Herbst 1996), 'extractive' and 'parasitic' (Clark 1998a), 'premodern' (Buzan 1998) and 'post-state' (Boone 1998).

The pervasiveness of these labels speaks not just of how accurate the framework of coercion and extraction is, but also of how it is applied to African politics. Therefore, a focus on the historical practices embedded in the present could bring about a richer view of contemporary statebuilding. State-making should 
be seen as an 'ongoing and open-ended process' rather than as a pathway to a particular institutional arrangement (Jung 2008: 40). These critiques also highlight the need to contextualise in order to understand the particularities of each process and place.

\section{The Africanist approach}

A focus on African states highlights that there are not different times in world history, but that different state configurations are the result of their historical interconnections. This is best put by Achille Mbembe in his notion of entanglement. Mbembe is representative of a heterogeneous Africanist school that has theorised African politics and social processes through their historicity. In theorising the nature of political power in Africa, Mbembe develops several useful arguments about state-making. Firstly, Mbembe argues that violence, extraction and symbolic representations are inseparable. Secondly, these take place across several divides that are ultimately irrelevant: dominants/dominated, formal/informal, local/global, public/private and historical/present. Finally, this can be grasped only through the notion of 'entanglement', meaning mutual transformations and syncretism, not only of actors and processes, but also of time and space. This notion includes practices, structures and systems of representation. These form the complex political space, called the 'postcolony'. For Mbembe:

The notion 'postcolony' identifies specifically a given historical trajectory - that of societies recently emerging from the experience of colonization and the violence which the colonial relationship involves. To be sure, the postcolony is chaotically pluralistic; it has nonetheless an internal coherence. It is a specific system of signs, a particular way of fabricating simulacra or re-forming stereotypes. [It] is characterized by a distinctive style of political improvisation, by a tendency to excess and lack of proportion, as well as by distinctive ways identities are multiplied, transformed, and put into circulation. But the postcolony is also made up of a series of corporate institutions and a political machinery that, once in place, constitute a distinctive regime of violence. In this sense, the postcolony is a particularly revealing, and rather dramatic, stage on which are played out the wider problems of subjection and its corollary, [in]discipline [- and of the emancipation of the subject]. (2001: 102-3, emphasis added $)^{5}$

At its core, what characterises 'the political' in post-colonial Africa is its own historicity, its pluralism, its institutional structure and its practices simultaneously constituted by violence, symbolism and a modus operandi of excess, improvisation and subjection. It is not surprising for Mbembe that the post-colonial state is 'itself a form of domination', due to the use of 'universal techniques (a state and its apparatus)' (2001: 60). What has shaped post-colonial states' 'institutional machinery' is the confrontation and symbiosis of the new educated 
elites (evolués) and the old colonial administration (Mbembe 2001: 40). Elites' struggles were aggravated by foreign interventions and the new ways in which African economies were inserted into the global economy. During the Cold War great powers forcefully removed democratically elected leaders across Africa (e.g. Lumumba, Krumah, Sankara, amongst others). The introduction of cash crops, of economic adjustments dictated by the Bretton Woods institutions and corporate pressures fostered externally backed factionalism, social inequality and even wars (Mbembe 2001: 41). Structural Adjustment Programmes (SAPs) dismantled much of the state infrastructure that even minimally sustained public services such as health and education. They also consolidated the African rural environment as an export-orientated production area and peasants as consumers of manufactured goods, including basic products like wheat and corn (Chossudovsky 1997).

The problem is that this historical trajectory, entangled with different actors and processes that are both national and international, is occluded by the accounts of the sources of conflict in the DRC and Africa in general. The literature on statebuilding, with the discourse of state failure, and the Africanist literature, with the discourse of 'neopatrimonialism', have made coercion and accumulation pathological practices of statecraft (Migdal and Schlichte 2005: 12-13; Wai 2012b). In fact, neopatrimonialism has turned into the fundamental characteristic of state failure, and hence conflict, in peacebuilding policy in the DRC (ISSSS 2013).

These accounts, however, raise many of the issues seen above in regard to the portrayal of an idealised European model versus the depoliticised and pathologised African state. Neopatrimonialism is a contemporary application of Weber's concept of patrimonialism. What Weber wanted to conceptualise is a type of authority which corresponds to what he calls 'traditional' societies, and captures the ways in which rule, distribution and accountability are exercised (Weber 1978: Ch. 12 and 13). The political and economic spheres are not autonomous rational, bureaucratised activities. These are enmeshed in social personal relations permeating the whole society. The problem is that Weber's concept has been misused by conceiving it as a totalising regime, where forms of accountability and control do not exist (Pitcher, Moran, and Johnston 2009: 129). The outcome of this approach has been to portray neopatrimonialism as an 'inherent', 'core' and even 'inevitable' feature of African politics and to see African politics as corrupt and backward (Bratton and Van de Walle 1994; Darnton 1994).

Neopatrimonialism, and the particular version of it that has been applied to account for the sources of conflict in the DRC, premises the nature of politics under a paradigm of unproductiveness. The problem is not the fact that there is violence and extraction, nor that authorities exercise them, but that they do so in a self-gain-seeking way through informal personal networks of patronage. 
Violence no longer produces public order or political contestation that is later channelled as institutional development.

As Crawford Young notes of the DRC, conflict is part of a trend in which 'armed groups exhausted anti-colonial and socialist ideologies, turning into gangs and jumping on the bandwagon of the resource revenues, fostered also by an increasing state weakness' (2002: 28). Rulers, no longer able to count on the support they received during the Cold War, have been forced to engage in criminal strategies of illegal trafficking and support of armed groups and to depend on non-state economic alliances (Reno 1998b). 'These rulers', Reno argues, 'reject the pursuit of a broader project of creating a state that serves a collective good or even of creating institutions that are capable of developing independent perspectives and acting on behalf of interests distinct from their rulers' personal exercise of power' (1998b: 1). The underlying assumption is that this violence has not served a social revolution or a developmental project as in Europe, giving rise to the view of the DRC as a 'cancer' (Dunn 2003: Ch. 5).

The argument about unproductive violence is closely related to the argument about unproductive rent extraction. Bayart argues that the 'politics of the belly', that is, 'the social struggles that make up the quest for hegemony and the production of the State bear the hallmarks of the rush for spoils in which all actors - rich and poor - participate in the role of networks' (2009: 235). Taking account of the historical trajectory of African politics, Bayart's argument concentrates on the failure of elites to transform people into labour and capital into investment. Rent extraction is presented only as a tool for gathering elite support and foster kin-links. In other words, there is economic production but the surplus is 'dilapidated' (Mbembe 1991c: 14). Challenging these theses, Mbembe notes that they:

seem to argue that it is only in Africa that the economy is inserted in social relations. And that ... [the economy] is not (as we imagine it must be) a domain separated, autonomous, of the social organisation. The relations of reciprocity, redistribution and circulation are, therefore, treated as 'extra-economic'. (1991c: 15)

Not only are there 'many economic regimes' but also '[t]he processes of accumulation are, consequently, multi-formed' (Mbembe 1991c: 16). Rent and productivity, far from being incompatible, are a source of authority (Mbembe 1991c: 17). In the DRC as in other places, military and economic actors provide a presence of authority.

Additionally, and taking Weber's stricter meaning of neopatrimonialism, if we look closely it is possible to see that 'patronage' is not a one-way approach, but is part of a system of mutual accountability. As Sophia Mappa points out, amongst most ethnic communities across Eastern DRC, authority is seen as an obligation that the chief cannot avoid. Authority is then premised on its value to serve and not for its capacity to command (Mappa 1998: 57-9). The role of 
reciprocity is not simply a matter of who gets the most riches from whom; it is a question of how the basis for distribution is established. Reciprocity could be seen as a contested and changing system by which a community establishes its norms of political and economic distribution. This may not be the result of legislation, but it is the result of negotiations in which a large part of the community, at the grassroots level, participates. This is not to argue that there are no corrupt politicians in the DRC who are actively promoting violence. The point here is to warn against making generalising descriptions of 'Congo politics' as neopatrimonial, and against premising the solution to this 'disease' on the development of forms of accountability and legitimacy that look like an idealised version of Western states, politics and democracy. Neopatrimonialism remains as a powerful simplifying account of both policy and literature, making the problems of the DRC something localised (De Grassi 2008: 21).

Mbembe's insights allow us to go beyond these simplifications and look further into the nature of political authority and the nature of domination. At the very least, we should understand that the DRC's political infrastructure is still conditioned by those broader historical and international political-economic processes. The DRC is also still based on a dual customary and administrative system, conditioning present sources of war, land conflicts and the deployment of authority. Customary chiefs today play a role as agents of state power in statebuilding strategies, or as necessary accomplices, either voluntarily or by force, for the extractive activities of multinational corporations (MNCs), armed groups and foreign governments. They also play a role in conveying resistance.

\section{Complexities and the challenge to resistance}

However, these complex relations and blurred divides lead Mbembe to cast doubt on resistance and argue that political relations are convivial. For Mbembe this means that the political landscape is more defined by an agency of subjection, of accommodation and 'entanglement' than by conflict between a category of resisters and dominants. Mbembe provides us here with a fundamental challenge that should be addressed. But let us briefly take a look at the present context of the DRC.

Since 1996, the DRC conflict has been characterised more by the targeting of the civilian population than by a conflict between armed groups. The civilian population have been systematically subjected to different forms of domination, through war, forceful displacement, killings, torture, sexual violence, forced labour and forced marriages (Human Rights Watch 2010; Pillay 2010: 289). This has at times been carried out by foreign and national armies, as well as by popular militias who were operating as part of a broader government strategy. Throughout the different wars, the DRC has gone through the toppling of a long-term dictator, two moments of genocide and several international 
interventions (by the African Union (AU), EU and UN). Although the most common strategy followed by the population against the war has been flight, civilians have actively participated in it in different roles, by either contesting or facilitating these forms of violence.

When Mbembe calls the African post-colonial political space an 'economy of death' and a 'regime of impunity', it partly resonates with the cacophony of events in the present DRC. What Mbembe wants to capture is, on the one hand, a condition, which is that of the nature of the political space in Africa as one that has become cohabited by those who kill and get killed; and, on the other hand, a sort of 'agency' of subjugation (Mbembe 2001: 11-8; 200-5). Killing and being killed are no longer the domain of any particular class or state agent or the domain of power. They are entangled, meaning actual, even intimate hybridisation between domination and subjugation.

The result, however, is an exaggerated theory of domination, or, as Judith Butler (1992) puts it, a sort of 'extravagant power'. While Mbembe rejects almost all social-theoretical concepts for doing violence to the nature of African politics, society and culture, his notion of domination as an inescapable desired 'masculine Thanatos' projects a vision of Africa that reproduces the assumptions he wants to challenge (Weate 2003: 39). Although this is a departure from earlier thinking, where he captured the fluidity of relationships, the modes of exercising domination and their subversion, here he is not only ignoring the capacity for insubordination within structures of domination but also the important relations of solidarity and mutual support that come to add to the relations of death and abuse. ${ }^{6}$

Resistance in colonial and post-colonial times has tended to subvert the terms of such cohabitation. For example, Mamdani points out that whereas the colonial state apparatus relied on ethnic and religious authorities, 'one finds it difficult to recall a single major peasant uprising over the colonial period that has not been either ethnic or religious in inspiration' (1996: 24). NzongolaNtalaja also argues that resistance in colonial times emerged in the "new structures that colonialism had itself created: colonial army, workers, camps and compulsory agricultural labour' (2002: 13). These analyses indicate the need to account for practices of resistance in the daily experience of relations of domination. Mbembe shows that relations of domination and resistance are not necessarily a story of good and bad, not even of the advance of an ethical agenda. This warning against simplifying an analysis of resistance leads to embracing the ambiguous realms in which relations of domination take place.

\section{Peacebuilding and state-making in Africa in the twenty-first century}

African states have generally been seen as the epitome of state failure. The DRC, along with Sierra Leone and Somalia, has featured prominently under this 
paradigm (Rotberg 2003). In the DRC the claims to legitimacy to carry out peacebuilding strategies have been built on the claim that peacebuilders have the capacity and knowledge to build the state apparatus and to enable policies that serve the goals of peace, development and democracy. These practices have also tended to reproduce formulae of indirect and shared government rather than crystallising in the centralised bureaucratic authority that peacebuilding policies have as a model. Authority has been shared, whether as a way of extending state authority, as a way of fostering alliances or as a compromise in the light of external and internal pressures. The exercise of coercion and extraction has been undertaken by a myriad of state and non-state actors. Coercive practices have also ensued from the fact that, as Chapter 3 will show, war has been directed against the civilian population. This is not just a feature of contemporary African states; as Krasner argues, 'rulers have frequently departed from the principle that external actors should be excluded from authority' (1999: 8). This has been done through invitation, intervention or negotiation. Having outlined above a schema of what the practices of statebuilding are, this section contextualises how plurality and decentralisation in the exercise of authority, coercion and extraction take place in the DRC and links these to the ways in which the discourse of statebuilding provides a legitimating mechanism for those practices and their actors.

\section{Sharing authority, sharing coercive and extractive capacity}

The forms of private indirect government that Mbembe speaks of have been a prominent way of asserting authority. This is particularly the case of the Kivus, where, aside from being a region that has traditionally been ruled through the power of customary chiefs, conflict is ongoing, adding a variety of actors that claim authority, coercive and extractive power. The DRC Government has shared means of coercion and tax extraction with armed groups, neighbouring countries and non-state actors. The UN and donors like the US and the UK have encouraged this option in order to have state representation in certain areas.

Both government and UN officials acknowledge that the presence of peacekeepers in those places where the Government is not present acts as a form of state authority. ${ }^{7}$ It is not uncommon to see multinational corporations, international non-governmental organisations (INGOs), UN mission representatives, the Forces Armées de la République Démocratique du Congo (FARDC) and poorly equipped government officials undertaking what could be seen as state functions. They patrol, provide civil order, tax the population, build infrastructure and provide arbitration, amongst other things. As Raeymaekers, Menkhaus and Vlassenroot state, 'the post-election security predicament in the DR Congo [...] combines elements of non-state governance such as military control over 
resources and cross-border regulation' (2008: 16). Hence, as shown in later chapters, they become targets of resistance.

For instance, peace agreements, encouraged by donors, have granted the National Congress for the Defence of the People (CNDP) - a Rwandan-backed armed group operating from about 2006 to 2010 - decision-making power in the Tripartite agreement to return refugees to the region. ${ }^{8}$ Although the DRC is the signatory to these agreements with the UN High Commission for Refugees (UNHCR) and the governments of Tanzania and of Rwanda, it was the CNDP that represented the DRC Government. In a US embassy cable, Ambassador Garvelink reported that

A UNHCR official candidly said that the Congolese delegation had signed the Tripartite 'for the gallery' and that much of the refugee return process was 'out of the government's control' - overseen by the CNDP parallel administration, which the official suggested would become even more entrenched following the recent GDRC [Government of the DRC] cabinet reshuffle which excluded the CNDP. (2010, para. 7)

This statement represents the widespread acknowledgement of Rwanda's presence in Eastern DRC. It also shows that there are different statebuilding projects taking place simultaneously, each having a difficult relationship with the promotion of peace and stability in the region (Shepherd 2010). However, more than a political compromise, in so far as this geopolitical social engineering is activated under the premise that the alternative is war, it is coercive. And in so far as it has an impact on land access and local political representation, it also has an extractive effect.

Shared authority is seen in cases where public authority has been left to multinational corporations. This was the case of Anvil Mining operations in the village of Kilwa, Katanga. ${ }^{9}$ Most villagers worked for the company, which operated as a de facto government. When in 2004 villagers revolted against the mining company, they created a poorly armed group to start looting the mine. Their reason was that the mine was not providing the village with jobs. The company had expelled most local workers except for the security guards. Anvil Mining in this case retaliated by flying the army into the village and massacring up to 100 people. Although this case caused outrage, not only due to the number of dead, but also due to how the MNC-army link operated as a despotic government, the strategy of allowing companies to operate as de facto governments is still in place.

In Twangiza, South Kivu, for example, the MNC Banro is the de facto government (Banro Representative 2010). The old town was on the site of a gold deposit that Banro wanted to mine. Negotiations with the customary chief and the mediation of a non-governmental organisation (NGO) whom Banro's 
representative was not allowed to name resulted in the moving of residents to a newly built town a few kilometres away from the old one. This is nothing new in the DRC, whose 'trinity' of colonial authority was exercised by the state, the corporation and the Church (Turner 2007: 28). However, in the context of war, mining companies take on special security roles (Hönke 2012). These roles include putting in place an indirect form of government by providing services to the population such as patrolling operations, recruitment of private security and cooperating with government intelligence agencies to assure civil peace. ${ }^{10}$ This is actually promoted by international agencies, especially international financial institutions and MONUC/MONUSCO, which seek to reconstruct state sovereignty that is able 'to legitimize deals with foreign firms and creditors' (Dunn 2001: 53). This strategy also 'leaves in place an interlocutor who acknowledges debts and provides a point of contact between foreign state officials and strongmen' (William Reno cited in Dunn 2001: 53). Still, the result is the plural constitution of political authority.

Authority is inseparable from its coercive and extractive capacity. As detailed more extensively in Chapter 3, the clearest example is the power-sharing agreements that came out of the 2002 Sun City agreements. Those who gained seats in government were not only warring parties but also those who had spoiled most resources during the war (UN Panel of Experts 2001). There has also been a policy ever since these agreements of reintegrating armed groups into the army but deploying them in the same areas where they had been operating before. This has officialised their tax levying, mine exploitation and informal order maintenance in those localities. This has been the case of the FDLR in the area of Shabunda in 2002, or the CNDP in 2007.

The military operations that have taken place since 2009 as an invigorated strategy against armed groups have had ambiguous effects in relation to the restoration of state authority. On the one hand, military operations have had the effect of giving the FARDC increasing control over mining (Global Witness 2010b). On the other hand, this is a sign of Rwandan interventionism. As Map 1.1 shows, FARDC has control of the greater number of mines. However, as many of the FARDC deployments in control of the mines are in fact ex-CNDP troops, these continued to serve the CNDP structure until recently and have continued to grant Rwanda access to mineral exploitation (UN Group of Experts 2012a, 2012b, para. 141).

These arrangements are certainly a feature of the political compromises necessary to end war, but they also go hand in hand with the strategy of deploying the military and police as a representation of state authority which has also largely been encouraged by the UN and DRC's main donors. The FARDC has been identified as the biggest human rights abuser, yet the consequences of having them deployed among the population are left for the population to deal with. Populations are claimed to give consent to this form of authoritarianism, to 


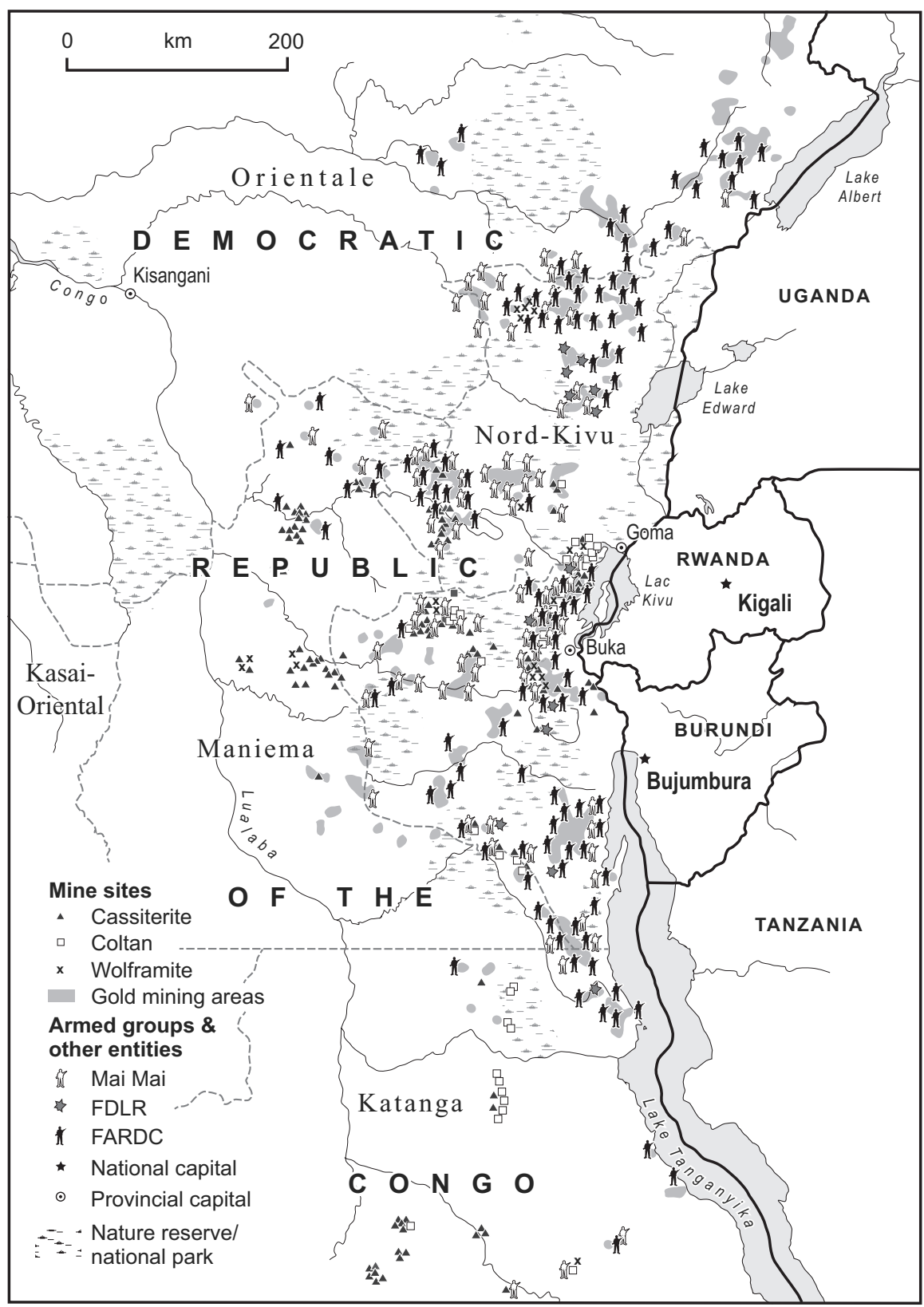

Map 1.1 Democratic Republic of Congo: presence at mine sites of armed groups and other entities

Source: Humanitarian Information Unit, US Government $(2016)^{11}$ 
which the general response is either to negotiate or to resist. This is not a parallelstate order but the one on which statebuilding in the DRC rests. Certainly, when the state is not particularly present, state agents and those on which consent is claimed can and do subvert roles. As is observed in Chapter 7, this means that subordinate classes might use the opportunity to enter into exchanges to mutually benefit from this relation, just as much as those representing authorities might use the opportunity to garner their support.

\section{High modernism as legitimacy}

The authority of statebuilding stems from a discourse that defines it as the process necessary to foster peace, promote democracy and enable economic development after conflict. Embedded in this discourse is a claim that asserts the knowledge and capacity for undertaking the task of statebuilding in addition to decision-making. This discourse portrays the state as an institution of protection and social change. On the one hand, war, oppression and poverty are the effect of state failure; on the other hand, the state is the embodiment of liberty, peace and development. These two premises have provided a sort of auto-generated legitimacy to statebuilders, making the state and their interventions public goods in themselves. Scott's vision of statebuilding as 'high modernism' fits here in that it is primarily a 'faith' and a 'belief'. In Scott's words, high modernism is:

the belief in the capacity of technicians and engineers to design and implement comprehensive new forms of living and production that would be superior - that is, more 'progressive', productive, healthy, and humane to anything thus far devised. (1999: 284)

Nevertheless statebuilding provides neither protection nor social change in the form that is stated. Chapter 4 will show how this failure gives way to a blame exchange between the DRC Government and the MONUC/MONUSCO. What is important to remark on here is that the discourse plays two important functions in terms of legitimacy: (1) it turns statebuilding into authority without the need for popular consent; and (2) it maintains legitimacy in the face of failure (Heathershaw 2008). To undertake statebuilding for the maintenance of international peace and security and for the protection of the population does not need negotiation or consent from the population. Since about 2010 in the Kivus an increased militarisation of the region, a subsequent increase in violence towards the civilian population and the fostering of networks of patronage against economic development mean that the effects of military/corporate rule are externalised onto the population while leaving few mechanisms of accountability standing.

Statebuilders, whether national or international, have no illusions that a Keynesian-type state will be built in the DRC in the near future, nor that their 
own practices are totally representative of what is stated in policy documents. A MONUC officer put it succinctly:

Our main focus is to build the minimum necessary for institutionalisation - the state will take 50 or 100 years to function. Civil society needs to play an advocacy role and also be a partner for reconstruction. We also need to rebuild the morale. (MONUC Political Affairs Officer (no. 7) 2009)

This is representative of a discourse that is deployed as an authority claim but that externalises any failures or blames onto the actual target. In this sense, the DRC is an instance of a pattern rather than an exception. Defining the problem as the lack of the state allows the solution to be defined in both technical and ethical ways. The technocraticism infused in statebuilding is also based on an ethic of 'doing something'. As Chandler argues, '[t]his simplistic focus sets up an interventionist discourse where western governments are seen to have the solution to problems of non-western states and where any western government action, regardless of its outcome, can generally be portrayed as better than acquiescence and passivity' (2003: 305). The underlying construction of local inadequacy simultaneously reifies an image of international responsibility, knowledge and capacity.

These practices are part of a logic of state authority assertion as much as a practice of domination. These aspects identify post-conflict statebuilding as a combination of the micro-politics of the DRC, the politics of the region and the politics of post-conflict statebuilding. This interaction reflects factors of historical continuity and change. How they are present through governing arrangements, proxy wars and UN-supported military operations leads us to contextualise how these practices take place. One of the distinctive features is that centralisation of authority, of coercion and extraction is not as central as the management of state authority throughout the territory is. However, this opens new sources of violence and does not always guarantee the extension of state authority. In this regard, the discourse of protection and social change provides a stronger mechanism for legitimacy, even in the face of failure, than popular consent does.

\section{Ambiguity and pluralism in peacebuilding and resistance}

This chapter has consolidated three key ideas that run through the book. Firstly, that peacebuilding is a process of asserting, consolidating and exercising state rule through coercive and extractive practices under a claim to legitimacy. This takes the form of improvised discharge and peacebuilding becomes mediated by multiple actors that create plural authority. Its discourse of social change and protection provides a way to claim legitimate authority. Secondly, the chapter has highlighted that resistance is rooted in the coercive and 
extractive practices embedded in the exercise of state rule and the assertion of state authority. The outcome of the peacebuilding process is not increasing rights and fostering of development but the externalisation of violence and of political agendas onto the population. Finally, and most importantly, the relationship between statebuilding and resistance speaks of a historically contingent process rather than a dynamic of liberal/international statebuilding and local resistance.

A critical reading of historical-sociological accounts of state formation, especially from an Africanist perspective, has provided the theoretical standpoint from which to observe how the nature of the political context determines practices of resistance. To this extent, practices of violence and extraction refer to patterns in state-making. However, it has been highlighted that not only concentration of coercive means and accumulation account for statebuilding. Following Mbembe, it has been shown that management, distribution and sharing can provide further coercive and extractive power and a way to exercise state authority. The claim to legitimacy and symbolic capital allows for these practices to be carried out under the premise of necessity and civilian protection.

The context of power relations in which multiple statebuilding projects coalesce impinges on resistance. Plural forms of domination give rise to a series of resistance strategies that make resistance heterogeneous. The internationally led programmes under which government and NGOs operate do not reproduce a different structure of authority or a different type of resistance. Zürcher (2011) sees this as 'the local' being imposed on 'the international'. But, as we have seen, it is more that these two spheres (international and local) do not provide adequate analytical categories for studying resistance or statebuilding. There is no 'international' statebuilding as an outcome. The insight that the DRC provides in this perspective is that peacebuilding is not so much a 'hybrid' of international and local agency as it is a process of state reconstruction that reflects the co-constituted nature of any given political institution and order in world politics.

This resonates with an everyday framework of resistance. The use of everyday theory in peace and conflict studies has been done to theorise the ways in which local practices have subverted internationally led policies. The tradeoff has been the loss of significant historical and sociological depth, not only in regard to the state-making process but also in regard to the political spaces where these processes have taken place. As such, if the everyday framework is to be fully applied, it would have to respond to the nature of statebuilding not as an international policy but as a process entangled in the historicity of Africa, muddled by ambiguities, improvisations, continuities and changes. The everyday framework would have to live up to the challenge of a 'chaotically pluralistic' political space and even become an insight into it. 


\section{Legitimacy, violence and extraction}

\section{Notes}

1 This book understands intervention in the broad sense that it has within peace and conflict studies. It includes forms of interference in the domestic affairs of another state, military acts of aggression and collective security mechanisms activated by the UN Security Council. It also includes a broad spectrum of conflict and post-conflict formulas, including humanitarian intervention, peacekeeping, peace-building strategies and capacity-building, amongst others (Brahimi 2000; Chandler, Chesterman, and Laakso 2007; UN General Assembly 1945: 1.1 and 2.7).

2 The centrality of war in this account leads Centeno to speak of it as the 'bellicist' account (2003: 11-26).

3 Tilly differentiates states according to their organisational structure, including: citystates, tribute-taking empires and nation-states (1990: 21-5).

4 The last census dates from 1984. For electoral purposes, in 2011 a registry of the adult population was undertaken (Carter Center 2012; Institut National de la Statistique 2012; UN Statistics Division 2010).

5 Please also note that on p. 103 of the cited English version the translation ends the quote with the word 'discipline'. However, the French version is slightly different: 'Voilà pourquoi la postcolonie pose, de façon fort aiguë, le problème de l'assujettissement, et de son corollaire, l'indiscipline ou, pour ainsi dire, de l'émancipation du sujet.' It is an important nuance. It is more likely that, after having identified the characteristics, features and structures of domination in the postcolony, Mbembe ends the paragraph reflecting on how subjection, indiscipline and emancipation play out in that political space (Mbembe 2000b: 140).

6 For Mbembe's earlier thinking see Mbembe (1988, 1991a, 1991b, 1991c). In his latest work, Mbembe refines the argument, asserting that change and emancipation are possible through a reinvention of the subject (Mbembe 2010).

7 This was a common view amongst 17 UN officers interviewed. A UN officer stated in an interview something quite obvious in Eastern Congo: 'in some places we are the only visible authority' (MONUC Civil Affairs Officer (no. 14), 2009). This was also shared by some government officials (e.g. North Kivu Provincial Assembly Representative 2010).

8 Discussed more extensively in Chapter 3.

9 The information in this paragraph comes from Deneault (2008: 67-71). See also: ABC Radio (2005).

10 Speaking in general of the link between businesses and the Government, a representative of a security company said that it supported and sometimes took over policing tasks (Security Contractor 2010).

11 Please note that this map does not show all mining sites or all armed groups' positions. For details on the compilation of the map and a statement of caveats please refer to the original source (Humanitarian Information Unit 2016). 